\title{
Suitable landscape classification systems for quantifying spatiotemporal development of riverine ecosystem services
}

\author{
K. R. Koopman ${ }^{1,5}$, D. C. M. Augustijn ${ }^{2,6}$, A. M. Breure ${ }^{1,3,7}$, H. J. R. Lenders ${ }^{1,8}$, and R. S. E. W. Leuven ${ }^{1,4,9}$ \\ ${ }^{1}$ Department of Environmental Science, Institute for Water and Wetland Research, Radboud University Nijmegen, P.O. Box 9010, \\ 6500 GL Nijmegen, The Netherlands \\ ${ }^{2}$ Twente Water Centre, University of Twente, P.O. Box 217, 7500 AE Enschede, The Netherlands \\ ${ }^{3}$ Centre for Sustainability, Environment and Health, National Institute for Public Health and the Environment, P.O. Box 1, 3720 BA \\ Bilthoven, The Netherlands \\ ${ }^{4}$ Department of Animal Ecology and Physiology, Institute for Water and Wetland Research, Radboud University, P.O. Box 9010, \\ 6500 GL Nijmegen, The Netherlands
}

\begin{abstract}
River systems provide numerous ecosystem services that contribute to human well-being. Biophysical quantification of spatiotemporal development of ecosystem services is useful for environmental impact assessments or scenario analyses of river management and could be done by linking biophysical indicators of relevant ecosystem services to landscape classifications that allow analyses of natural and management-induced changes in riverscape characteristics. We analyzed 126 case studies in which landscape classification systems (LCSs) were applied over the period 1989-2014. LCSs were mostly applied at regional (subnational) scales and linked to ecosystem services in 46 case studies. Ecosystem services were linked to landscape patches based on quantitative (monetary or biophysical) or semiquantitative approaches. Only 6 case studies linked ecosystem services to river systems. The number of ecosystem services quantified by biophysical indicators and linked to landscape classes also was limited. Moreover, the spatiotemporal development of these indicators in relation to landscape changes is poorly elaborated. Six selected LCSs were considered suitable for application to river systems and biophysical quantification of spatiotemporal development of ecosystem services (e.g., Coordination of Information on the Environment [CORINE] Land Cover, River Ecotope Classification). Future research should be directed to developing sound indicators for quantification of river ecosystem services and analyzing how these services develop spatiotemporally in relation to natural and anthropogenic changes of the riverscape.
\end{abstract}

Key words: land cover, land use, landscape unit classification, ecosystem services, rivers, management measures

Rivers form complex and dynamic systems that involve many hydromorphological and ecological interactions (Petts and Amoros 1996, Ward et al. 2002). Rivers and the surrounding landscape should be considered one riverscape in which the interaction of terrestrial and aquatic elements (e.g., patch quality, patch boundaries, patch context, patch connectivity, scale, and organisms) determine how the riverscape (i.e., river system) is structured, functions, and affects ecological patterns and processes (Wiens 2002). Thus, a river system encompasses the river and the riparian zone, i.e., the part of the terrestrial landscape from the high water mark of the stream toward the uplands, where vegetation may be in- fluenced by high water levels or flooding and the ability of the soil to hold water (Weissteiner et al. 2016).

River systems provide important societal functions, such as navigation, food, timber, and water supply (Gore and Petts 1989, Wang et al. 2010, Vermaat et al. 2013, Large and Gilvear 2014), which are threatened by increasing pressures including climate change, land use, and population growth (Petts and Amoros 1996, Meyer et al. 1999, Vörösmarty et al. 2000, Tockner and Stanford 2002, Richter et al. 2003). Safeguarding and restoring these functions requires sustainable river management that takes riverine processes into account (Gore and Petts 1989, Petts 1996, 2009, Downs

E-mail addresses: ${ }^{5}$ k.koopman@science.ru.nl; ${ }^{6}$ d.c.m.augustijn@utwente.nl; ${ }^{7}$ t.breure@science.ru.nl; ${ }^{8}$ r.lenders@science.ru.nl; ${ }^{9}$ r.leuven@science.ru.nl

DOI: 10.1086/696612. Received 1 May 2017; Accepted 17 October 2017; Published online 8 January 2018.

Freshwater Science. 2018. 37(1):190-204. @ 2018 by The Society for Freshwater Science. 
and Gregory 2014). A focus on making more use of natural processes (nature-based solutions; European Commission 2015) instead of traditional management approaches may result in less costly and more sustainable river management. The ecosystem services concept enables identification of beneficial services provided by ecosystems that contribute to human well-being (Maes et al. 2013). The number and type of services provided by an ecosystem (e.g., a river system) can help determine its value. Moreover, this value can be included in the cost-benefit balance of river management. During the last 2 decades this concept has gained ground in environmental science and policy (Costanza et al. 1997, Daily 1997, De Groot et al. 2002, MEA 2005, TEEB 2010c, Maes et al. 2013, Chaudhary et al. 2015). Definitions and classifications of ecosystem services differ throughout the literature (Wallace 2007, Crossman et al. 2013). However, the definition of the Millennium Ecosystem Assessment (MEA 2005) is widely accepted and, therefore, adopted in this paper: 'the benefits people obtain from ecosystems'. The MEA triggered several global, multilateral, and national programs, including The Economics of Ecosystems and Biodiversity (TEEB) and the Common International Classification of Ecosystem Services (CICES). These programs encouraged development of new approaches for mapping, quantifying, and valuing ecosystem services (TEEB 2010a, b, c, Haines-Young and Potschin 2011, Chaudhary et al. 2015). Ecosystem services often are quantified in monetary or biophysical units (Konarska et al. 2002, Scolozzi et al. 2012, Felipe-Lucia et al. 2014) or are approached semiquantitatively by giving the landscape capacity scores for delivering ecosystem services based on expert judgment (Burkhard et al. 2009).

Quantifying management-induced changes in the provision of these ecosystem services can help evaluations of river management by comparing societal management costs to benefits obtained from ecosystem services. This process requires knowledge of the spatiotemporal development of riverine ecosystem services in relation to river management measures. Authors of several reviews on mapping ecosystem services focused on indicator use, appropriate scales, and potentials of remote-sensing techniques (Egoh et al. 2012, Martínez-Harms and Balvanera 2012, Andrew et al. 2014, Chaudhary et al. 2015, de Araujo Barbosa et al. 2015, Malinga et al. 2015, Boerema et al. 2017). Multiple tools and models are available to quantify or map ecosystem services (Nelson et al. 2009, Tallis and Polasky 2009, Crossman et al. 2013, Villa et al. 2014). Gilvear et al. (2013) have developed a semiquantitative framework to assess the effects of river rehabilitation measures on riverine ecosystem services. However, methods for the biophysical quantification of the spatiotemporal development of riverine ecosystem services in relation to management measures are lacking. Expressing ecosystem services in biophysical units requires indicators that act as a proxy (Van Wijnen et al. 2012).

Ecosystem services are linked to the quality, functioning, and spatiotemporal development of landscapes. Suc- cession processes cause the landscape to change (e.g., from pioneer vegetation to grassland), which leads to changes in the ecosystem services it provides. Development of ecosystem services indicators requires knowledge of the landscape's attributes (e.g., type of vegetation, water, and soil), disturbance processes (e.g., floods or human interventions), and vegetation succession. Thus, classification of the landscape into ecologically homogeneous units (i.e., landscape patches) based on land attributes, such as land form, soil, and vegetation, is needed. Numerous systems or frameworks that classify the landscape into these units (i.e., landscape classification systems [LCSs]) are described in the scientific literature, e.g., the European Environment Agency's Coordination of Information on the Environment (CORINE) land cover database (Burkhard et al. 2009, 2012, Geijzendorffer and Roche 2013), the River Ecotope Classification (REC; Van der Molen et al. 2003, Geerling et al. 2009), and the European Union's Global Land Cover (GLC2000) system (Mayaux et al. 2006, Schulp and Alkemade 2011). These LCSs often are based on data retrieved from remote sensing. One of the benefits of remote sensing-based LCSs is the relatively quick application and classification of new areas compared to LCSs that are based on exhaustive field studies. Remote sensing techniques often can identify landscape features (elevation, vegetation, rock, and water) in one step, making it relatively easy to link multiple ecosystem services to the landscape. Over the years the development of remote sensing techniques has greatly increased the number of sensor parameters, such as more spectral bands, that can be measured and classified automatically. Satellite remote sensing systems, notably Landsat and moderate-resolution imaging spectroradiometer (MODIS) can be used to measure more spectral bands than previous sensors, thereby enabling more discrimination between vegetation types resulting in higher accuracies and more distinctive classes in landscape classification systems (Townshend et al. 1991, Leuven et al. 2002, Mertes 2002, Mulla 2013, Maccherone and Frazier 2016). Moreover, the use of classification software, such as the commercial decision tree software See5 (Quinlan 1993), has provided improved classification results for LCSs like the National Land Cover Database (NLCD; Homer et al. 2007). LCSs are developed for specific reasons, causing them to differ in characteristics, such as spatial resolution (or scale), range coverage, or specificity (patch type, e.g., terrestrial or aquatic habitats). These characteristics also influence each other. For instance, the high coverage range of a global classification system results in a lower spatial resolution arising from aggregation of landscape types (Zonneveld 1989). Therefore, the choice to use a specific LCS depends on the goal and scale of a study and the available data.

Several LCSs are in use across the globe, and some have been used for mapping and quantifying ecosystem services in general and for specific environments including rivers (Martínez-Harms and Balvanera 2012, Andrew et al. 2014, Large and Gilvear 2014, Malinga et al. 2015). Linking indi- 
cators for ecosystem services to LCSs is thought to be a feasible approach for developing tools that could be used to quantify riverine ecosystem services worldwide. Furthermore, landscape classification is a unifying approach in river science and management and facilitates multi- and interdisciplinary analyses. Selection and application of an LCS to a study area is the first step for identifying and subsequently quantifying the ecosystem services provided by a study area. Moreover, use of the LCS as an integral system for linking multiple types of ecosystem services to the landscape and quantifying them enables assessment of trade-offs involving ecosystem services.

A sound way to select LCSs that are applicable to river systems and suitable for ecosystem services quantification is lacking. The aim of our study was to: 1) review, analyze, and compare LCSs that are used to classify terrestrial and aquatic habitats into ecologically homogeneous units; 2) identify LCSs suitable for classifying the stream and floodplain parts of river systems; and 3) select those LCSs suitable to quantify the spatiotemporal development of riverine ecosystem services in relation to river management. Our paper comprises a review of currently used methods for linking ecosystem services to LCSs, application of these LCSs at global to river floodplain scales, and selection of suitable LCSs for spatiotemporal quantification of riverine ecosystem services. First, we analyze the range of spatial coverage and scale of application of available LCSs. Second, we review the literature on linkage of ecosystem services to various LCSs and the number of LCSs designed for or applied to river systems. Third, we discuss a selection of LCSs suitable for linkage to riverine ecosystem services and their quantification. Last, we draw conclusions and make recommendations for further research.

\section{METHODS}

\section{Literature search}

ISI Web of Science (www.isiknowledge.com) was used to search papers on LCSs and their links to ecosystem services. Seven searches were performed with different search terms related to landscape classification, ecosystem services, and rivers (Table S1). Several papers were retrieved repeatedly during the literature searches. Duplicates were removed from the results, leading to a total of 579 papers published between 1945 and 02 June 2016 (final search date; Table S1). These papers were screened for further selection. LCSs had to fit our definition: An LCS describes the landscape in multiple classes (landscape elements) that are distinctive from each other and spatially explicit. Land-cover systems also were regarded as fitting our description because different land covers are distinct and spatially explicit. LCSs that distinguished purely anthropogenic landscape classes, such as urban areas or private gardens, were omitted from the analysis. Relevant references on LCSs cited in the papers analyzed were included in the literature review.

\section{Literature analysis}

The papers were analyzed according to predetermined criteria (Fig. 1). LCSs had to divide the landscape into homogeneous landscape units. The range of coverage of LCSs was estimated at global, continental, national, or regional scales. These 4 scales were used to indicate the scales of mapped case studies. Each application of an LCS to a specific area was treated as a separate case study. Applicability of an LCS to rivers was assessed by analyzing the application of LCSs in riverine case studies or by deciding whether the landscape classes covered riverine systems.

The case studies linked multiple types of ecosystem services to LCSs in 3 ways. Two were quantitative approaches and used either monetary or biophysical units to express ecosystem services (ratio scales). The $3^{\text {rd }}$ approach was semi-quantitative and used ordinal scales to indicate the capacity of landscape classes for delivering ecosystem services (e.g., $0-5$, where $0=$ no relevant capacity for delivering ecosystem services and $5=$ very high relevant capacity for delivering ecosystem services; Burkhard et al. 2009). In cases for which a landscape classification had not yet been linked to ecosystem services, the possibility of establishing such a linkage was determined by assessing the homogeneity and (a)biotic characteristics of its landscape classes. The ecosystem services linked to LCSs were categorized according to the Millennium Ecosystem Assessment (MEA 2005) as provisioning, regulating, supporting, or cultural services. Last, the (potential) use of LCSs for mapping landscape changes (e.g., senescence, vegetation succession, and rejuvenation) was assessed by determining the compatibility of LCSs with transition matrices.

\section{RESULTS}

\section{Landscape classification: scales and coverage ranges}

In total, 103 papers contained LCSs that fit our definition and did not distinguish purely anthropogenic classes. These papers contained 126 case studies conducted in the period 1989-2014 (Appendix S1). The number of case studies increased with decreasing scale (i.e., from global to regional; Fig. 2). Most case studies were performed at a regional scale and used LCSs with regional coverage. However, LCSs with national, continental, and global coverage also were applied to case studies at a regional scale. Case studies at continental and global scales applied only LCSs with a similar spatial coverage.

\section{Landscape classification and linkage to ecosystem services across the globe}

Most of the case studies that applied LCSs to classify landscapes and (potentially) linked ecosystem services were done in Europe, followed by North America, Asia, and Africa (Fig. 3A, B). Several landscape-classification case studies were done in South America, but only 1 linked ecosystem services to the LCS. One case study classified a 
What are suitable landscape classification systems (LCS) for riverine ecosystem services assessment?

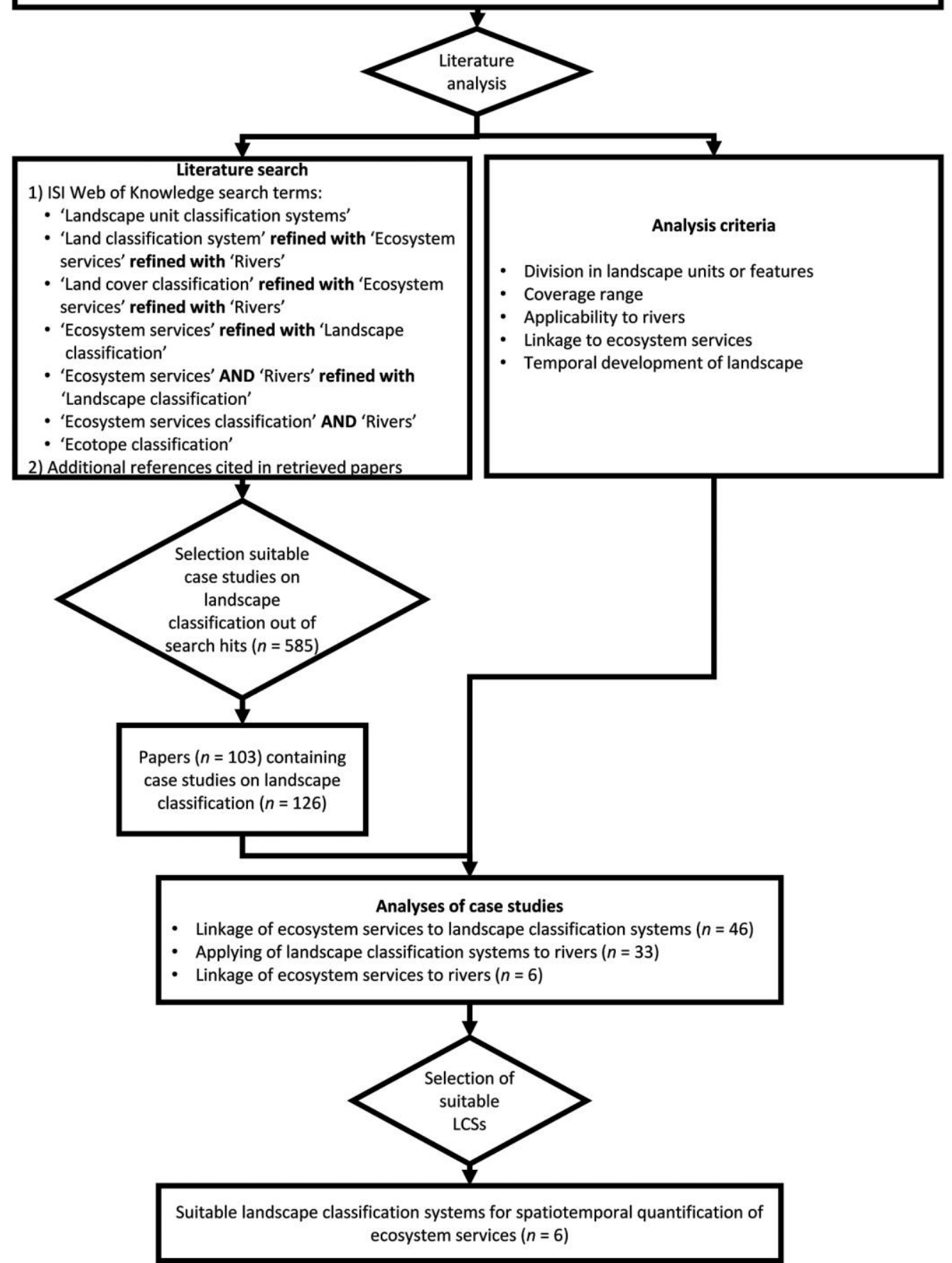

Figure 1. Flow chart showing the structure of this literature review and the selection of suitable landscape classification systems (LCSs) for spatiotemporal quantification of ecosystem services in river systems.

landscape in Oceania, but it did not include ecosystem services. Two global case studies were retrieved of which 1 also linked ecosystem services (Fig. 3A, B). Six of the case studies that linked ecosystem services to LCSs were applied to river systems in either Europe or Asia (Fig. 3C).
The first case studies that explicitly linked ecosystem services to an LCS were published by Konarska et al. (2002). These case studies linked ecosystem services quantitatively to the landscape in monetary units. Three more case studies based on the monetary approach were pub- 


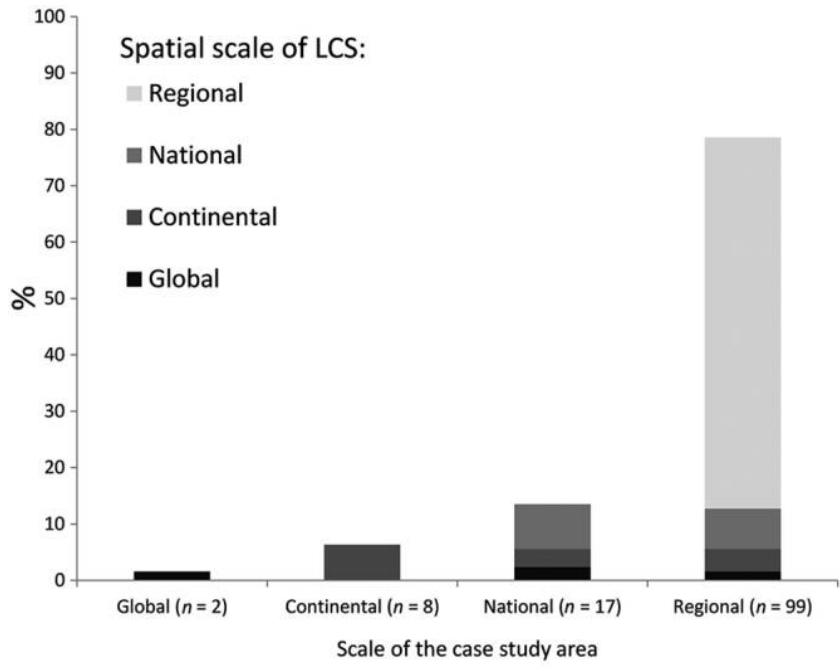

Figure 2. Spatial scale of the case-study areas that were classified and the total coverage of the landscape classification systems (LCSs) that were used. Data contains case studies in general $(n=126)$.

lished in 2006 (Fig. 4). A new method that appeared in 2009 was based on use of semiquantitative (expert judgment) and biophysical quantitative approaches to link ecosystem services to CORINE landscape classes (Burkhard et al. 2009). After this publication, the number of case studies based on semiquantitative and biophysical quantification methods increased steeply. Recent studies were mostly focused on semiquantitative approaches to ecosystem services. Regulating ecosystem services were linked most often in the case studies, followed by provisioning, cultural, and supporting services. In some case studies, all ecosystem services were grouped and their total value was estimated. However, the number of studies in which ecosystem ser- vices were grouped and linked was lower than the number of times supporting services were linked.

\section{Landscape classification systems applied to riverine case studies}

Only 33 (26\%) of the 126 case studies were focused on river systems. In most of these cases, the LCSs were developed to cover both the main river channel and its adjacent floodplains. In addition, riverine case studies were sometimes mapped based on LCSs that were not designed specifically for rivers (i.e., generic systems) but were applicable to rivers (Fig. 5).

\section{Landscape classification systems for riverine ecosystem services quantification}

Six LCSs were used in $17 \%$ of all case studies and were considered suitable for linkage to riverine ecosystem services (Table 1). CORINE was the most used LCS. It covers most of Europe and is based on various types of remote sensing data, such as Landsat and Satellite Pour l'Observation de la Terre (SPOT) imagery and aerial photography. CORINE classifies the landscape based on a 3-level hierarchical system, in which the lowest level has 44 homogeneous classes based on vegetation/crops, water(bodies), ice/snow cover, soil, rock, and artificial surfaces (EEA 1995). CORINE was applied to terrestrial landscapes and to riverine case studies. In several studies, ecosystem services were linked, often semiquantitatively, to the classes of CORINE. Burkhard et al. (2009) were among the first investigators to link ecosystem services to CORINE classes. These authors used expert judgment for semiquantitative scoring of the capacities of landscape classes to deliver different ecosystem services, resulting in a matrix table with the capacities of all 44 CORINE landscape classes. This matrix has been used and adapted multiple

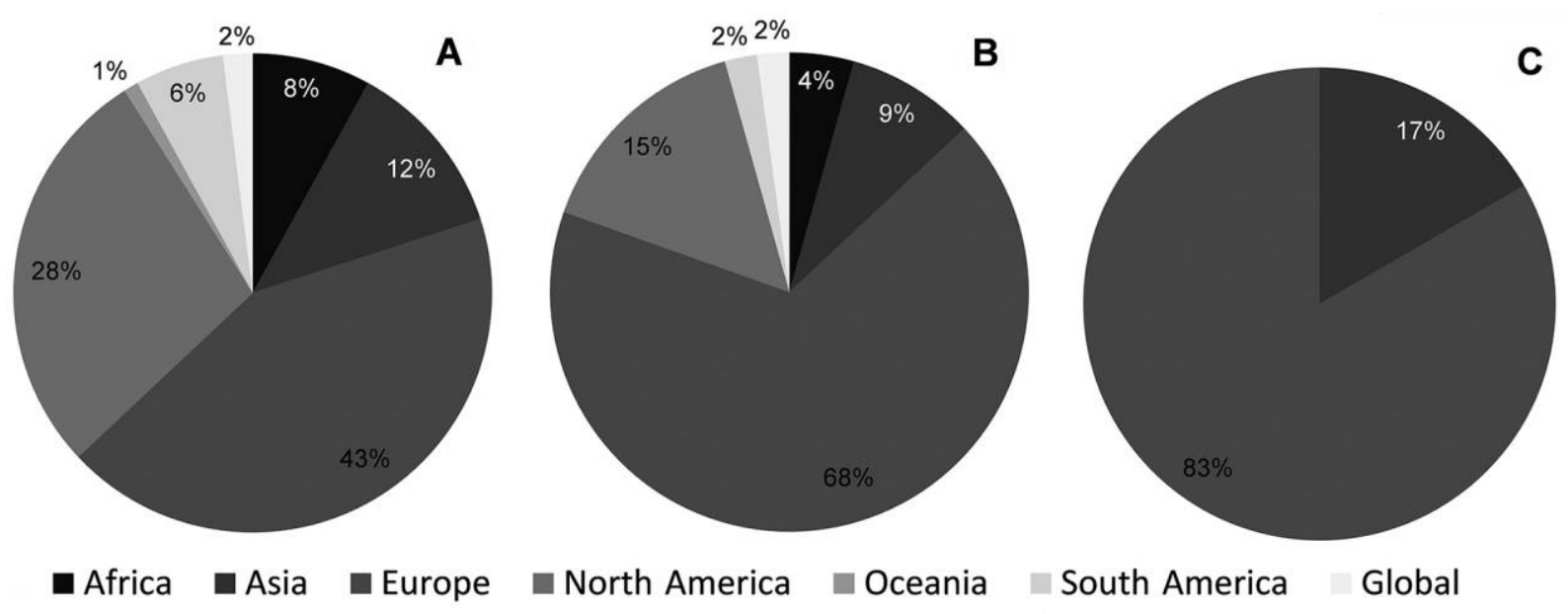

Figure 3. The relative number of case studies on each continent in which landscape classification was applied $(n=126)(\mathrm{A})$, ecosystem services were linked to landscape classification systems $(\mathrm{LCSs})(n=46)(\mathrm{B})$, and landscape classification systems (LCSs) were applied to rivers and linked to ecosystem services $(n=6)(C)$. 


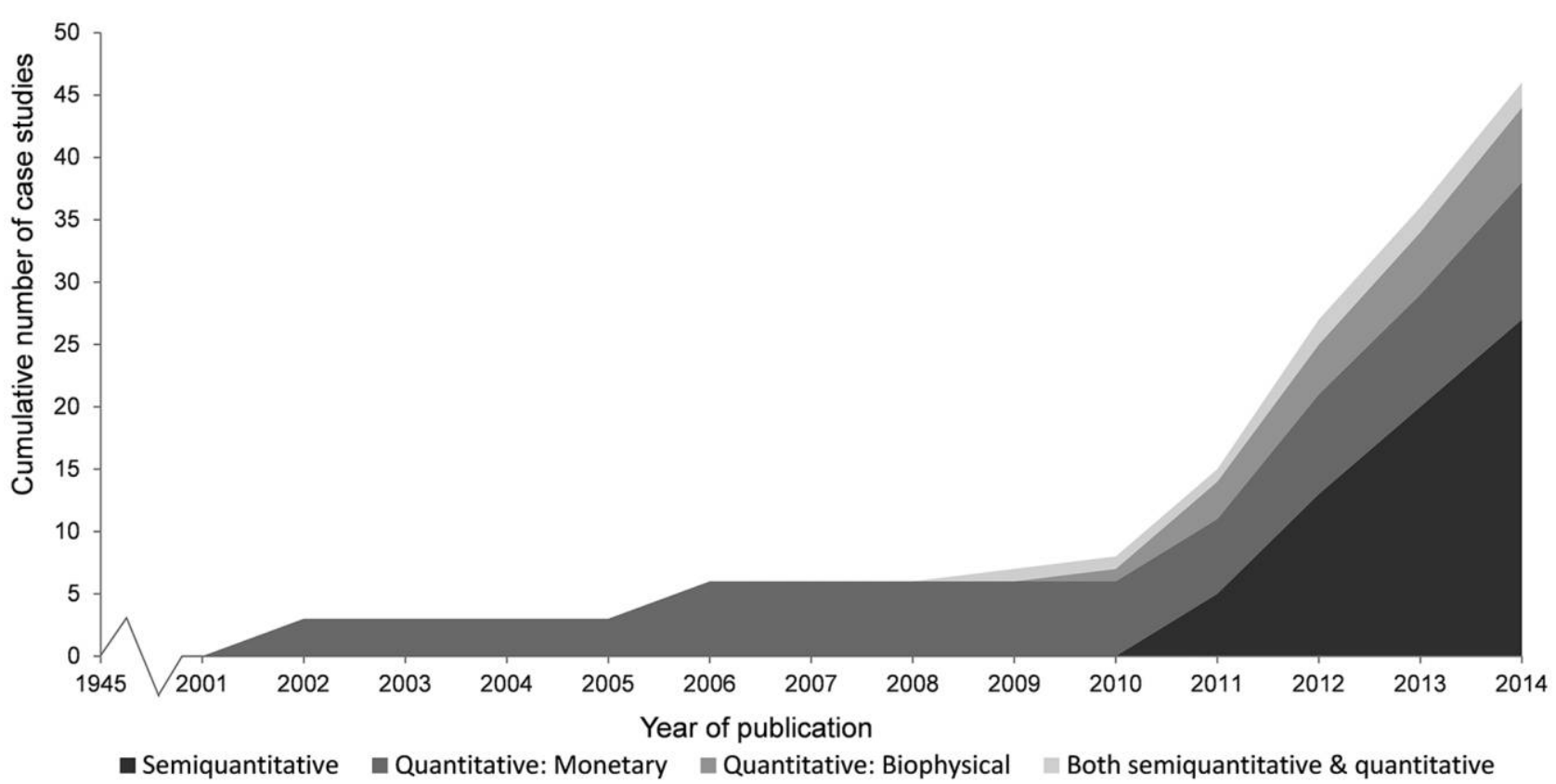

Figure 4. The cumulative number of case studies that linked ecosystem services to a landscape classification system between 2002 and $2014(n=46)$.

times (Burkhard et al. 2012, 2014, Nedkov and Burkhard 2012, Schneiders et al. 2012, Skokanová 2013, Stoll et al. 2015). In addition to the semiquantitative approach, Burkhard et al. $(2009,2012)$ provided quantitative approaches for 2 ecosystem services, food provisioning and energy provisioning, based on indicators (e.g., energy yield from crops in GJ ha ${ }^{-1} \mathrm{y}^{-1}$ or wind energy in GJ ha ${ }^{-1} \mathrm{y}^{-1}$ ) that were linked to landscape classes. Vermaat et al. (2013) also used indicators (e.g., drinking water in $\mathrm{m}^{3} \mathrm{ha}^{-1} \mathrm{y}^{-1}$ or $\mathrm{CO}_{2}$ sequestration in ton $\mathrm{Cha}^{-1} \mathrm{y}^{-1}$ ) and presented some biophysical quantitative ranges for several ecosystem services that could be delivered by specific CORINE classes. CORINE has a Minimum Mappable Unit (MMU) of $100 \times 100 \mathrm{~m}$ making it specifically applicable to national and continental scales (EEA 1995, Schulp and Alkemade 2011, Scolozzi et al. 2012), but it has been applied successfully in some regional case studies (Burkhard et al. 2009, 2012). CORINE also was used to study the temporal development of the landscape and its ecosystem services (in monetary terms) (Scolozzi et al. 2012).

The National Land Cover Database (NLCD) was linked to ecosystem services with a monetary approach by Konarska et al. (2002), who calculated the total ecosystem services value of the USA. It has an MMU of $30 \times 30 \mathrm{~m}$, which makes it applicable to national scales (states). The NLCD has not been applied in riverine case studies, but it could cover riverine areas. Its 21 homogeneous classes were based on vegetation/crops, waterbodies, ice/snow cover, soil, rock, and artificial surfaces (Konarska et al. 2002, Fry et al. 2011).

The Dutch Water Ecotope Classification (WEC) was designed to cover the major water systems in The Nether- lands and includes the River Ecotope Classification (REC) for river channels and floodplains (Van der Molen et al. 2000, 2003, Willems et al. 2007, Geerling et al. 2009). The REC divides the riverine landscape into 82 spatially explicit ecotopes, which are homogeneous ecological units based on vegetation, flooding, soil, and river/floodplain management. No case studies that linked ecosystem services to the REC were retrieved. The REC operates at scales of 1:25,000 or 1:10,000 and has an MMU of $20 \times 20 \mathrm{~m}$, which makes it suitable for application at regional and, potentially, national scales.

The UK LCM2000 is a satellite-imagery-based land cover map of the UK that was calibrated with field data (Fuller et al. 2002). At its lowest level, it contains 72 homogeneous classes based on the same properties as CORINE and the NLCD, but it includes (grassland) management. The MMU of the UK LCM2000 is $71 \times 71 \mathrm{~m}$ and is available as a raster with a $25 \times 25-\mathrm{m}$ grid. An adapted version of the UK LCM2000 was applied to a regional riverine case study in which its landscape classes were further refined to link ecosystem services, based on cadastral maps and the Integrated Admission Control System (Brown and Castellazzi 2014). The UK LCM 2000 is considered suitable for national and regional case studies (Fuller et al. 2002).

The Midwest Land Cover Data set (MLCD) covers the Midwest region of the USA and was constructed by combining the NLCD with the LANDFIRE Existing Vegetation Layers (LANDFIRE EVT) (LANDFIRE 2007) and Cropland Data Layer (CDL) classifications (Mueller and Ozga 2002). Additional yield and management variables were added from the MODIS-based irrigated lands (Ozdogan 


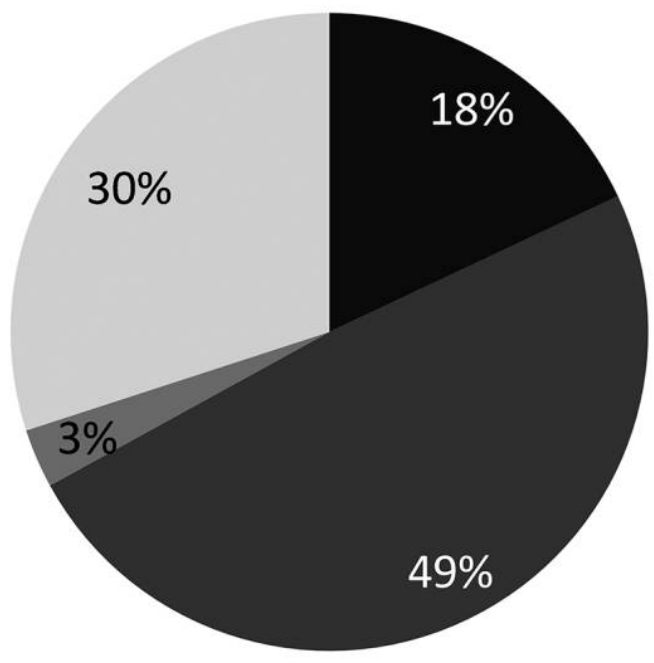

- River channel

- River channel and floodplain - Floodplain

Generic

Figure 5. The relative specificity of landscape classification systems (LCSs) that were applied in riverine case studies $(n=33)$. Generic LCSs were not specifically developed for rivers but to classify landscapes with both aquatic and terrestrial components.

and Gutman 2008), SSURGO soil map unit crop yields (NRCS 1995), NASS country/district-level crop yields (USDA NASS 2007), and ARMS state-level tillage practices and fertilizer/pesticide applications (ARMS 2005) (Mehaffey 2011, 2012). The MLCD has an MMU of $30 \times 30 \mathrm{~m}$ and was developed for assessment of ecosystem services provisioning (mostly crop yields) on regional and potentially national scales in the Midwest region of the USA. The MLCD was not applied to a riverine case study. However, its 178 homogeneous classes were based on the same properties as the NLCD, making it applicable to river systems. The MLCD is the only classification besides CORINE that has been used to study temporal development of the landscape and the ecosystem service corn yield (Table 1; Mehaffey 2012). The adapted UK LCM2000 used by Brown and Castellazzi (2014), REC, and MLCD differ from the other LCSs because they incorporate additional data, such as flooding, management, and crop yields, with the landcover data.

The GLC2000 has not been applied in riverine case studies but its classes were considered suitable to cover river systems because they were homogeneous and based on the same properties as CORINE and the NLCD (Mayaux et al. 2006). The GLC2000 has an MMU of $825 \times 825 \mathrm{~m}$ and was considered suitable for global and continental scales.
It was used for the Millennium Ecosystem Assessment (MEA 2005, Mayaux et al. 2006). Schulp and Alkemade (2011) applied the GLC2000 at a national scale (The Netherlands) to assess the ecosystem service pollination. However, the resolution of the GLC2000 appeared to be too coarse to assess ecosystem services at this level.

\section{DISCUSSION}

\section{Landscape classification: scales and coverage range}

Case studies were applied on all 4 predefined scales. The high number of case studies based on LCSs with regional coverage might indicate its improvement over remotesensing techniques. This improvement has enabled more accurate classification results on smaller spatial (regional) scales and reduced application costs, thereby decreasing the threshold for developing a region-specific LCS (Leuven et al. 2002, Turner et al. 2003, Xie et al. 2008). The regional LCSs often were designed specifically for the area in which the case study was done (38\% of all case studies), which hampers their application to other areas of interest. Because of their limited applicability, these systems were referred to as landscape classifications, whereas LCSs were designed to classify areas in multiple case studies. For practical reasons, the term LCSs is used as a collective noun in this discussion.

\section{Landscape classification and linkage to ecosystem services across the globe}

Most of the case studies in which LCSs were applied and linked to ecosystem services were performed in Europe and North America. Only a few studies were done on other continents (i.e., Africa, Asia, South America, and Oceania), highlighting a knowledge gap for (developing) countries on these continents. The higher number of studies in Europe and North America than elsewhere might be explained by the need for and attention to efficient spatial planning in these continents because of increasing pressures of urbanization and population growth (Tockner and Stanford 2002). The low number of studies in developing countries might be explained by limited availability of (financial) resources for landscape classification. Furthermore, the European Union (EU) has coordinated landuse policies and subsidy systems (e.g., the Common Agricultural Policy) and has directed its member states to quantify their ecosystem services actively as part of Action 5 of the EU Biodiversity strategy to 2020 (Maes et al. 2013, 2014, Malinga et al. 2015). A possible explanation for the lower number of case studies linking ecosystem services in North America compared to Europe might be the use of the term ecosystem services. Other terms to describe ecosystem services, such as multipurpose projects (A. Serra-Llobet, personal communication), environmental services, ecological services (Chaudhary et al. 2015), or landscape services (Hainz-Renetzeder et al. 2015), may be more common in the USA than in Eu- 
Table 1. Suitability of common landscape classification systems (LCSs) for modeling spatiotemporal development of river ecosystem services at various scales $(+=$ suitable, $\pm=$ potentially suitable, $-=$ not suitable). $\mathrm{MMU}=$ minimum mappable unit, $\mathrm{CORINE}=$ Coordination of Information on the Environment Land Cover, NLCD = National Land Cover Database, REC = River Ecotope Classification, LCM = Land Cover Map, MLCD = Midwest Land Cover Data, and GLC = Global Land Cover.

\begin{tabular}{|c|c|c|c|c|c|c|c|c|c|}
\hline \multirow[b]{2}{*}{ Name } & \multirow{2}{*}{$\begin{array}{c}\text { Number } \\
\text { of case } \\
\text { studies }\end{array}$} & \multirow{2}{*}{$\begin{array}{l}\text { Linked to } \\
\text { ecosystem } \\
\text { services }\end{array}$} & \multirow{2}{*}{$\begin{array}{l}\text { Resolution } \\
\text { (MMU) }\end{array}$} & \multicolumn{4}{|c|}{ Scale of applicability } & \multirow{2}{*}{$\begin{array}{c}\text { Spatial } \\
\text { coverage }\end{array}$} & \multirow{2}{*}{$\begin{array}{c}\text { Temporal } \\
\text { development } \\
\text { of ecosystem } \\
\text { services }^{\mathrm{a}}\end{array}$} \\
\hline & & & & Global & Continental & National & Regional & & \\
\hline CORINE & 12 & Yes & $100 \times 100 \mathrm{~m}$ & - & + & + & \pm & Europe & Yes \\
\hline NLCD & 2 & Yes & $30 \times 30 m$ & - & - & + & - & USA & No \\
\hline REC & 2 & No & $20 \times 20 \mathrm{~m}$ & - & - & \pm & + & $\begin{array}{l}\text { Dutch river } \\
\text { systems }\end{array}$ & No \\
\hline UK LCM2000 & 1 & Yes & $\begin{array}{c}71 \times 71 \mathrm{~m} \\
(25 \times 25 \mathrm{~m} \text { raster })\end{array}$ & - & - & + & + & UK & No \\
\hline MLCD & 2 & Yes & $30 \times 30 \mathrm{~m}$ & - & - & \pm & + & $\begin{array}{l}\text { Midwestern } \\
\text { USA }\end{array}$ & Yes \\
\hline GLC2000 & 2 & Yes & $825 \times 825 \mathrm{~m}$ & + & + & - & - & Global & No \\
\hline
\end{tabular}

a This column indicates whether or not the LCS has already been applied to study temporal changes in ecosystem services

${ }^{\mathrm{b}}$ Refers to the adapted UK LCM2000 by Brown and Castellazzi (2014)

rope. The use of these different terminologies on various continents might have biased our results. However, Abson et al. (2014) and Chaudhary et al. (2015) report that ecosystem services is the most common term in the scientific literature and is used by most international organizations and initiatives. Moreover, the concept originated in the USA (Pistorius et al. 2012), making potential bias of our literature search limited. Chaudhary et al. (2015) showed that most of the research output on ecosystem services has been produced in the USA, which probably is explained by a focus on aspects of ecosystem services other than linkage to LCSs.

In the earliest case studies by Konarska et al. (2002), ecosystem services were linked to common land classes and their monetary values were given according to Costanza et al. (1997). The solely monetary quantification of ecosystem services probably was triggered by this approach (Gómez-Baggethun et al. 2010). The rapid increase of published case studies after the publication of the major ecosystem services papers (e.g., MEA 2005, TEEB 2010a, b, c, Haines-Young and Potschin 2011) also was noted in other reviews (Egoh et al. 2012, Chaudhary et al. 2015). In particular, the semiquantitative approach based on expert judgment was used increasingly after 2010. A possible explanation for this increase might be the advantage of a relatively quick assessment of ecosystem services in the case study area, compared to other quantitative methods that require more time-consuming data acquisition and calculations. In spite of experts' subjectivity and qualitative estimates, this approach enables incorporation of stakeholder views on the societal importance (e.g., scores) and spatial distribution of specific ecosystem services in the area (Martínez-Harms and Balvanera 2012, Rutgers et al. 2012). The semiquantitative approach also offers the potential to value or com- pare delivery of ecosystem services among or within landscape classes (e.g., by comparing the capacity scores given to the landscape classes and ecosystem services).

Regarding the types of ecosystem services linked, our results were similar to those of other reviews (Egoh et al. 2012, Martínez-Harms and Balvanera 2012, Malinga et al. 2015). The higher number of linked regulating and provisioning services probably can be explained by their increasing importance for decision-making regarding important topics, such as climate change and population growth (MartínezHarms and Balvanera 2012). Regulating services, such as $\mathrm{C}$ sequestration and flood mitigation, have become increasingly important when considering atmospheric $\mathrm{CO}_{2}$ levels and water safety, whereas provision of food and drinking water is needed to nourish the growing population (Rosegrant et al. 2002, Lackner 2003, Schröter et al. 2005, Nedkov and Burkhard 2012, Stürk et al. 2014). Moreover, regulating and provisioning services often are regarded more favorably than cultural services, which often are considered a sidegoal in the literature (Martinez-Harms and Balvanera 2012, Milcu et al. 2013, Malinga et al. 2015, Grêt-Regamey et al. 2017). The field of cultural ecosystem services lacks a wellestablished research framework, a clear definition, and study methods, making these services more difficult to quantify (Milcu et al. 2013).

Despite multiple examples of linkage of ecosystem services to landscape classes, use of landscape classes can lead to difficulties caused by errors and inaccuracies in mapping of ecosystem services (Martínez-Harms and Balvanera 2012). Eigenbrod et al. (2010b) showed that land-cover-based proxies provided a poorer fit than field data, especially on local scales. The major problem when using the land-cover approach is generalization error, i.e., proxy indicators are re- 
trieved from the literature and applied to landscapes other than the one from which they were obtained and are treated as though they are constant across the entire mapped area (Plummer 2009, Eigenbrod et al. 2010a, b, Van der Biest 2015). Another difficulty is that not all ecosystem services can be captured by land-cover alone and require additional information (Van der Biest 2015, Boerema et al. 2017). Some provisioning and regulating services, such as vegetative biomass production and $C$ sequestration, are easy to calculate by multiplying harvest indicators and $\mathrm{C}$ content by the surface area of the associated landscape class (Tolkamp et al. 2006), whereas other services, such as fish biomass production, flood protection, and most cultural services, require additional indicators before they can be quantified (Maes et al. 2014). For instance, indicators relevant to quantifying the flood protection service of an area include water storage capacity of soils, the roughness factor, and seasonal state of the floodplain vegetation, rainfall quantity and intensity, and the overall water retention capacity of the floodplains, which is partly determined by the presence of dikes or other elevations and the floodplain surface area (Nedkov and Burkhard 2012, Maes et al. 2014). The floodplain surface area can be derived from land-cover data, but other indicators must be linked to the LCS to quantify flood protection as an ecosystem service. Nedkov and Burkhard (2012) accomplished this task by combining CORINE with topographic data, field work (assessing the potential damage to the area from flooding), and statistical data on flood events. Cultural ecosystem services also are not directly quantifiable based on land cover alone because they depend on the presence of specific scenery and infrastructure. Potential additional indicators to land cover could be the number of visitors of specific areas or the number of photographs posted on social media (Maes et al. 2014, Richards and Friess 2015).

Use of site-specific data and avoiding generalization are not always possible when developing general tools that can be used to classify riverine landscapes across the globe. Acquiring site-specific data for each case study would be very time-consuming and costly. Moreover, quantification of some ecosystem services requires information in addition to land cover. In these cases, LCSs should be combined with additional maps, models, or databases. For example, Weissteiner et al. (2016) created an extensive database of European riparian zones by combining different types of observation data, such as digital elevation maps, hydrological and soil databases, vegetation indices, and land cover/ landuse data. Such databases provide excellent potential for deriving indicators for quantifying ecosystem services. We consider LCSs to be a good basis for riverine ecosystem services assessment because they are used by investigators in multiple disciplines in river science. Applying these systems for ecosystem services assessment facilitates interdisciplinary collaboration in decision making.

Quantification of spatiotemporal development of ecosystem services is feasible because of their link to landscape classes, and the subsequent mapping can be combined with additional information, but knowledge of the temporal development of ecosystem services and their links to landscape classes is very limited. Authors of only 1 case study assessed the effect of landscape changes on ecosystem services in monetary terms (Scolozzi et al. 2012). In addition, only 1 study of indicator-based biophysical development of ecosystem services in time was found (Mehaffey et al. 2012). Biophysical quantification of ecosystem services gives insight to the actual amount of a specific service provided, whereas semiquantitative methods only identify the type of services and give a rough estimation (score) of their amount. Monetary quantification does give insight to the amount of a service that is provided, but the diversity of valuation techniques increases the uncertainty in the values assigned to ecosystem services (Farber et al. 2002, Johnson et al. 2012). Thus, biophysical quantification enables a more objective assessment of the ecosystem services that are provided. Knowledge of dynamic biophysical development of river systems should be translated to succession of riverine landscape classes and their ecosystem services.

\section{Landscape classification systems applied to riverine case studies}

Classification of the stream and floodplains is necessary for quantification of riverine ecosystem services. Mapping of river systems can extend from coarse catchment scales (continental/national) to finer floodplain scales (national/ regional). Ecosystem services assessment on finer floodplain scales is preferred because of its higher resolution and subsequent higher accuracy in linking and quantifying ecosystem services. The number of river-specific LCSs applicable to these smaller floodplain scales is limited. Hence, some LCSs applied to terrestrial case studies also were assessed on their applicability to rivers and their potential for linkage to ecosystem services (Table 1). This approach allowed us to select more LCSs for assessment of spatiotemporal development of riverine ecosystem services.

Developing LCSs for river systems is challenging because of their highly dynamic landscapes. Processes including vegetation succession, rejuvenation, and landuse change constantly reshape the landscape (Tabacchi et al. 1998, Baptist et al. 2004, Zhang and Schilling 2006). Moreover, riverine landscapes often are reshaped by construction of infrastructure (e.g., groynes, dams, levees, side channels) designed to ensure water safety and safeguard important river functions during high and low discharges, respectively (Nohara et al. 2006, Palmer et al. 2008). Such infrastructure subsequently influences the development of the landscape. In addition, the vegetation in the riparian zone, the transition zone between stream and land, can be highly variable because of ecological succession and hydromorphological processes, such as flooding, sedimentation, and erosion (Swanson et al. 1982, Gregory et al. 1991, Baptist et al. 2004, Geerling et al. 2006). 
Succession enables development from herbaceous into woody stages with higher and perennial vegetation, whereas flooding, erosion, and sedimentation can set back the vegetation to earlier successional stages (e.g., cyclic rejuvenation to pioneer vegetation). LCSs designed to map river systems should contain classes that are applicable to the highly dynamic riverine landscapes.

Another important challenge to LCS-based quantification of ecosystem services is limitations associated with existing data. At present, most ecosystem services assessments are semi-quantitative. These assessments provide rapid identification of available ecosystem services, but they do not indicate how much of the services can be capitalized and to what extent. This lack of quantitative data limits the application and sustainable use of ecosystem services in riverine management.

\section{LCSs for quantification of riverine ecosystem services}

Our results included some examples of the potential of CORINE to provide biophysical quantification of ecosystem services via indicators. However, biophysical quantification has been done for a limited number of CORINE landscape classes and ecosystem services, and the effects of landscape changes on indicator values and ecosystem services have been assessed rarely. Nevertheless, CORINE is suitable for ecosystem services assessment. CORINE has been applied to regional case studies, but its resolution is quite coarse $(\mathrm{MMU}=100 \times 100 \mathrm{~m})$ for application at the floodplain level. Moreover, its classes do not permit sufficient distinction of aquatic elements/patches for application on floodplain scale. We recommend using CORINE only at larger scales (e.g., catchment or river basin). CORINE was designed for Europe, so its application on other continents probably will require modifications. A less time-consuming approach would be to use an LCS designed specifically for the continent of interest. For example, investigators conducting case studies on quantifying or mapping riverine ecosystem services in the USA could use the NLCD. Applying the NLCD for biophysical quantification of ecosystem services will require development of ecosystem services indicators linked to the NLCD classes. The NLCD's MMU is $30 \times 30 \mathrm{~m}$, which suggests it is applicable to regional scales, but its relatively low number of landscape classes $(n=21)$ and lack of different aquatic classes prevent it from distinguishing enough landscape diversity on the floodplain scale. The NLCD would be more applicable at catchment or riverbasin scales.

The REC is applicable to regional and, potentially, national riverine case studies because it has relatively high resolution $(\mathrm{MMU}=20 \times 20 \mathrm{~m})$. However, the REC was developed for The Netherlands, and it cannot be applied directly to river systems outside The Netherlands because of the possibility of missing landscape types (ecotopes). However, with some adjustments (inclusion of extra ecotope types) the REC probably can be applied to river systems out- side The Netherlands. The REC has not been linked to ecosystem services yet, but the characteristics of its ecotopes are well described (Van der Molen et al. 2000, 2003, Willems et al. 2007), allowing identification of their ecological functions and potential delivery of ecosystem services. After identifying these qualitative links between ecotopes and ecosystem services, the next step would be to develop indicators that link ecosystem services to ecotopes.

Other LCSs that are suitable for regional riverine ecosystem service quantification are the adapted UK LCM2000 and the MLCD for the UK and USA, respectively. The original UK LCM2000's resolution (MMU $=71 \times 71 \mathrm{~m}$ ) is more suitable for application at the catchment than floodplain scale. The raster data set $(25-\times 25$-m grid $)$ probably offers more possibilities for application at the floodplain scale, but a more reliable approach would be to use the adapted UK LCM2000 (Brown and Castellazzi 2014). Use of the adapted UK LCM2000 for biophysical quantification of ecosystem services will require the development and linking of indicators for ecosystem services. In contrast, the MLCD already contains crop-yield data and can quantify this provisioning service, but indicators need to be developed and linked to quantify other ecosystem services. The MLCD can be mapped at $30 \times 30 \mathrm{~m}$ and its classes can cover riverine areas, so it is suitable for application at the floodplain scale. Applying the adapted UK LCM2000 outside the UK and applying the MLCD outside midwestern USA probably will require addition of extra landscape classes. These regionally applicable LCSs contain additional attributes to the land-cover data, such as data on flooding, management, and (yields of) crops, and improve knowledge of landscape development, which is valuable for ecosystem services assessment and enables more accurate linking and quantification of spatiotemporal development of ecosystem services. Including these additional data in assessments at larger scales probably will be difficult and costly because of the substantial effort for data collection.

The LCSs mentioned above are considered suitable for linkage to ecosystem services at continental, national, and regional scales. However, for global initiatives at river-basin scales, LCSs with global coverage, such as the GLC2000, probably are preferable. So far, indicators linking ecosystem services to the GLC2000 and knowledge of their development in relation to (management-induced) landscape changes are limited.

All 6 of the LCSs classified the landscape into homogeneous units, although the properties on which the units were based may differ slightly. The homogeneous nature of these units enables precise identification of the biotic and abiotic processes that occur in the unit. Once these processes are identified, the ecological functions of the unit can be identified, and specific ecosystem services can be linked. Linkage of ecosystem services to these LCSs will enable assessment of the spatial distribution of ecosystem services, but the temporal development of these ecosystem 
services is poorly elaborated. At present, only CORINE and the MLCD have been used to study temporal development of ecosystem services (Mehaffey 2012, Scolozzi et al. 2012). The use of transition matrices enables incorporation of succession into other landscape classes and, subsequently, incorporation of different ecosystem services (Muller and Middleton 1994). However, the resolution of the LCSs is important for determining the reliability of the temporal development of the landscape. For example, some pixels might contain several landscape classes (e.g., grassland and softwood shrubs). With LCSs like CORINE, the dominant landscape class often is used to identify the content of the pixel (EEA 1995). At coarse resolutions (e.g., $100 \times 100 \mathrm{~m}$ ), this approach can lead to misleading depictions of temporal changes. For instance, a marginal change may cause the pixel to transition to another landscape class. This transition would appear abrupt but might have reached the transition threshold after developing for some time. At higher resolutions (e.g., $20 \times 20 \mathrm{~m}$ ), this threshold would be reached sooner and the dominant landscape class would be spread over a smaller area (smaller pixel size). Transition matrices enable quantification of spatiotemporal development of landscapes and ecosystem services, but caution is needed when interpreting landscape transitions, especially at coarse resolutions.

\section{Conclusions and recommendations}

Many LCSs have been developed across the world for different applications and spatiotemporal scales. In total, $38 \%$ of the landscape classifications were developed for specific areas, which hampers their use in other areas. Several LCSs have been linked to ecosystem services based on various approaches (e.g., monetary, biophysical, semiquantitative). Regulating and provisioning ecosystem services were most often considered in these approaches. Riverine ecosystem services were linked to riverine landscape classes in 6 case studies. In a few case studies, ecosystem services were quantified biophysically and their development was assessed in relation to landscape changes. Studies are lacking of indicatorbased biophysical quantification of riverine ecosystem services and their spatiotemporal development in relation to management measures. The lack of quantitative data limits quantification of ecosystem services and complicates appropriate assessments of their use and capitalization for sustainable river management.

Our review yielded 6 LCSs suitable for quantifying the spatiotemporal development of ecosystem services in river systems (CORINE, NLCD, REC, adapted UK LCM2000, MLCD, and GLC2000) at different scales (regional to global), depending on their resolution. Landscape classes (units or patches) must be homogeneous and unequivocally described to identify the ecosystem functions they provide and to link them to appropriate indicators. Moreover, quantification of some riverine ecosystem services (e.g., flood protection and cultural services) requires additional information and a combination of land-cover data with other maps and types of indicators. Next steps will be to identify and to develop missing indicators for ecosystem services that can be linked to landscape classes. Special attention should be directed toward identifying how these indicators develop over time and space because of natural dynamics and various types of river management-induced landscape changes. This goal can be achieved by applying a back-casting approach to riverine areas in which various management measures have been used. Once indicators have been elaborated, they can be incorporated into model tools that quantify the effects of riverine management measures on ecosystem services.

\section{ACKNOWLEDGEMENTS}

Author contributions: KRK designed the research, gathered and analyzed the literature, constructed the figures, and wrote large parts of the paper. DCMA, AMB, and HJRL contributed to the research design, data interpretation, and text of this paper. RSEWL acquired funding for this project and contributed to the research design, data interpretation, and text of this paper.

Part of the results of this study were presented and discussed at the $2^{\text {nd }}$ International Integrative Sciences Rivers Conference in Lyon, 22-26 June 2015. This research is part of the research program RiverCare, supported by the Dutch Technology Foundation (STW), which is part of The Netherlands Organization for Scientific Research (NWO), and which is partly funded by the Ministry of Economic Affairs under grant number P12-14 (Perspective Programme). The study was conducted in the specific STW research project: 13519 (RiverCare E2 Ecosystem services of floodplain rehabilitation), co-financed by Rijkswaterstaat, Rijksinstituut voor Volksgezondheid en Milieu (RIVM), Arcadis, Deltares, and Bureau Waardenburg.

\section{LITERATURE CITED}

Abson, D. J., H. von Wehrden, S. Baumgärtner, J. Fischer, J. Hanspach, W. Härdtle, H. Heinrichs, A. M. Klein, D. J. Lang, P. Martens, and D. Walmsley. 2014. Ecosystem services as a boundary object for sustainability. Ecological Economics 103:29-37.

Andrew, M., M. A. Wulder, and T. A. Nelson. 2014. Potential contributions of remote sensing to ecosystem service assessments. Progress in Physical Geography 38:328-353.

ARMS (Agricultural Resource Management Survey). 2005. Tillage and fertilizer/pesticide homepage of the agricultural resources management survey. National Agriculture Statistics Service, Washington, DC. (Available from: https://data.ers .usda.gov/reports.aspx? ID =17883)

Baptist, M. J., W. E. Penning, H. Duel, A. J. M. Smits, G. W. Geerling, G. E. M. van der Lee, and J. S. L. van Alphen. 2004. Assessment of the effects of cyclic floodplain rejuvenation on flood levels and biodiversity along the Rhine River. River Research and Applications 20:285-297.

Boerema, A., A. J. Rebelo, M. B. Bodí, K. J. Esler, and P. Meire. 2017. Are ecosystem services adequately quantified? Journal of Applied Ecology 54:358-370.

Brown, I., and M. Castellazzi. 2014. Scenario analysis for regional decision-making on sustainable multifunctional land uses. $\underline{\mathrm{Re}}$ gional Environmental Change 14:1357-1371. 
Burkhard, B., M. Kandziora, Y. Hou, and F. Müller. 2014. Ecosystem services potentials, flows and demands: concepts for spatial localization, indication and quantification. Landscape Online 34:1-32.

Burkhard, B., F. Kroll, F. Müller, and W. Windhorst. 2009. Landscapes' capacities to provide ecosystem services: a concept for land-cover based assessments. Landscape Online 15:1-22.

Burkhard, B., F. Kroll, S. Nedkov, and F. Müller. 2012. Mapping ecosystem services supply, demand and budgets. Ecological Indicators 21:17-29.

Chaudhary, S., A. McGregor, D. Houston, and N. Chettri. 2015. The evolution of ecosystem services: a time series and discoursecentered analysis. Environmental Science and Policy 54:2534.

Costanza, R., R. d'Arge, R. de Groot, S. Farber, M. Grasso, B. Hannon, K. Limburg, S. Naeem, R. V. O’Neill, J. Paruelo, R. G. Raskin, M. van den Belt, and P. Sutton. 1997. The value of the world's ecosystem services and natural capital. Nature 387:253-260.

Crossman, N. D., B. Burkhard, S. Nedkov, L. Willemen, K. Petz, I. Palomo, E. G. Drakou, B. Martín-Lopez, T. McPhearson, and K. Boyanova. 2013. A blueprint for mapping and modelling ecosystem services. Ecosystem Services 4:4-14.

Daily, G. C. 1997. Nature services: societal dependence on natural systems. Island Press, Washington, DC.

de Araujo Barbosa, C. C., P. M. Atkinson, and J. A. Dearing. 2015. Remote sensing of ecosystem services: a systematic review. Ecological Indicators 52:430-443.

De Groot, R. S., M. A. Wilson, and R. M. J. Boumans. 2002. A typology for the classification, description and valuation of ecosystem functions, goods and services. Ecological Economics 41:393-408.

Downs, P. W., and K. J. Gregory. 2014. River channel management. Routledge, New York.

EEA (European Economic Area). 1995. CORINE land cover report. Commission of the European Communities, Brussels, Belgium.

Egoh, B., E. G. Drakou, M. B. Dunbar, J. Maes, and L. Willemen. 2012. Indicators for mapping ecosystem services: a review. Report EUR 25456 EN. Publications Office of the European Union, Luxembourg City, Luxembourg.

Eigenbrod, F., P. R. Armsworth, B. J. Anderson, A. Heinemeyer, S. Gillings, D. B. Roy, C. D. Thomas, and K. J. Gaston. 2010a. Error propagation associated with benefits transfer-based mapping of ecosystem services. Biological Conservation 143:24872493.

Eigenbrod, F., P. R. Armsworth, B. J. Anderson, A. Heinemeyer, S. Gillings, D. B. Roy, C. D. Thomas, and K. J. Gaston. 2010b. The impact of proxy-based methods on mapping the distribution of ecosystem services. Iournal of Applied Ecology 47: 377-385.

European Commission. 2015. Towards an EU research and innovation policy agenda for nature-based solutions and re-naturing cities. Publications Office of the European Union, Luxembourg City, Luxembourg.

Farber, S. C., R. Costanza, and M. A. Wilson. 2002. Economic and ecological concepts for valuing ecosystem services. Ecological Economics 41:375-392.

Felipe-Lucia, M., F. A. Comin, and E. M. Bennet. 2014. Interactions among ecosystem services across land uses in a floodplain agroecosystem. Ecology and Society 19:20.
Fry, J. A., G. Xian, S. Jin, J. A. Dewitz, C. G. Homer, Y. Limin, C. A. Barnes, N. D. Herold, and J. D. Wickham. 2011. Completion of the 2006 national land cover database for the conterminous United States. Photogrammetric Engineering and Remote Sensing 77:858-864.

Fuller, R. M., G. M. Smith, J. M. Sanderson, R. A. Hill, and A. G. Thomason. 2002. The UK land cover map 2000: construction of a parcel-based vector map from satellite images. Cartographic Journal: The World of Mapping 39:15-25.

Geerling, G. W., A. M. J. Ragas, R. S. E. W. Leuven, J. H. van den Berg, M. Breedveld, D. Liefhebber, and A. J. M. Smits. 2006. Succession and rejuvenation in floodplains along the river Allier (France). Hydrobiologia 565:71-86.

Geerling, G. W., M. J. Vreeken-Buijs, P. Jesse, A. M. J. Ragas, and A. J. M. Smits. 2009. Mapping river floodplain ecotopes by segmentation of spectral (CASI) and structural (LiDAR) remote sensing data. River Research and Applications 25:795813.

Geijzendorffer, I. R., and P. K. Roche. 2013. Can biodiversity monitoring schemes provide indicators for ecosystem services? Ecological Indicators 33:148-157.

Gilvear, D. J., C. J. Spray, and R. Casas-Mulet. 2013. River rehabilitation for the delivery of multiple ecosystem services at the river network scale. Journal of Environmental Management 126:30-43.

Gómez-Baggethun, E., R. de Groot, P. L. Lomas, and C. Montes. 2010. The history of ecosystem services in economic theory and practice: from early notions to markets and payment schemes. Ecological Economics 69:1209-1218.

Gore, J. A., and G. E. Petts. 1989. Alternatives in regulated river management. CRC Press, Boca Raton, Florida.

Gregory, S. V., F. J. Swanson, W. A. McKee, and K. W. Cummins. 1991. An ecosystem perspective of riparian zones. BioScience 41:540-551.

Grêt-Regamey, A., E. Sirén, S. H. Brunner, and B. Weibel. 2017. Review of decision support tools to operationalize the ecosystem services concept. Ecosystem Services 26B:306-315.

Haines-Young, R., and M. Potschin. 2011. Common international classification of ecosystem services (CICES): 2011 update. European Environment Agency, Brussels, Belgium.

Hainz-Renetzeder, C., A. Schneidergruber, M. Kuttner, and T. Wrbka. 2015. Assessing the potential supply of landscape services to support ecological restoration of degraded landscapes: a case study in the Austrian-Hungarian trans-boundary region of Lake Neusiedl. Ecological Modelling 295:196-206.

Homer, C., J. Dewitz, J. Fry, M. Coan, N. Hossain, C. Larson, N. Herold, A. McKerrow, J. N. VanDriel, and J. Wickham. 2007. Completion of the 2001 National Land Cover Database for the conterminous United States. Photogrammetric Engineering and Remote Sensing 73:337-341.

Johnson, K. A., S. Polasky, E. Nelson, and D. Pennington. 2012. Uncertainty in ecosystem services valuation and implications for assessing land use tradeoffs: an agricultural case study in the Minnesota River Basin. Ecological Economics 79:71-79.

Konarska, K. M., P. C. Sutton, and M. Castellon. 2002. Evaluating scale dependence of ecosystem service valuation: a comparison of NOAA-AVHRR and Landsat TM datasets. Ecological Economics 41:491-507.

Lackner, K. S. 2003. A guide to $\mathrm{CO}_{2}$ sequestration. Science 300: 1677-1678. 
LANDFIRE. 2007. LANDFIRE Project. US Department of Agriculture, Forest Service, US Department of Interior, Washington, DC. (Available from: https://www.landfire.gov/index .php)

Large, A. R. G., and D. J. Gilvear. 2014. Using Google Earth, a virtualglobe imaging platform, for ecosystem services-based river management. River Research and Applications 31:406-421.

Leuven, R. S. E. W., I. Poudevigne, and R. M. Teeuw (editors). 2002. Application of GIS and RS in river research. Backhuys Publishers, Leiden, The Netherlands.

Maccherone, B., and S. Frazier. 2016. MODIS Moderate Resolution Imaging Spectroradiometer [online]. National Aeronautics and Space Administration, Washington, DC. (Available from: https://modis.gsfc.nasa.gov/)

Maes, J., A. Teller, M. Erhard, C. Liquete, L. Braat, P. Berry, B. Egoh, P. Puydarrieux, C. Fiorina, F. Santos-Martín, M. L. Paracchini, H. Keune, H. Wittmer, J. Hauck, I. Fiala, P. H. Verburg, S. Condé, J. P. Schägner, J. S. Miguel, C. Estreguil, O. Ostermann, J. L. Barredo, H. M. Pereira, A. Stott, V. Laporte, A. Meiner, B. Olah, E. R. Gelabert, R. Spyropoulou, J. Petersen, C. Maguire, N. Zal, E. Achilleos, A. Rubin, L. Ledoux, P. Murphy, M. Fritz, C. Brown, C. Raes, S. Jacobs, P. Raquez, M. Vandewalle, D. Connor, and G. Bidoglio. 2013. Mapping and assessment of ecosystems and their services. An analytical framework for ecosystem assessments under Action 5 of the EU biodiversity strategy to 2020 . 1 report. Publications Office of the European Union, Luxembourg City, Luxembourg.

Maes, J., A. Teller, M. Erhard, P. Murphy, M. L. Paracchini, J. I. Barredo, B. Grizzetti, A. Cardoso, F. Somma, J. Petersen, A. Meiner, E. R. Gelabert, N. Zal, P. Kristensen, A. Bastrup-Birk, K. Biala, C. Romao, C. Piroddi, B. Egoh, C. Fiorina, F. Santos, V. Naruševičius, J. Verboven, H. Pereira, J. Bengtsson, K. Gocheva, C. Marta-Pedroso, T. Snäll, C. Estreguil, J. S. Miguel, L. Braat, A. Grêt-Regamey, M. Perez-Soba, P. Degeorges, G. Beaufaron, A. Lillebø, D. A. Malak, C. Liquete, S. Condé, J. Moen, H. Östergård, B. Czúcz, E. G. Drakou, G. Zulian, and G. Lavalle. 2014. Mapping and assessment of ecosystems and their services. Indicators for ecosystem assessment under Action 5 of the EU Biodiversity Strategy to 2020. 2 report. Publications Office of the European Union, Luxembourg City, Luxembourg.

Malinga, R., L. J. Gordon, G. Jewitt, and R. Lindborg. 2015. Mapping ecosystem services across scales and continents: a review. Ecosystem Services 13:57-63.

Martínez-Harms, M. J., and P. Balvanera. 2012. Methods for mapping ecosystem service supply: a review. International Journal of Biodiversity Science, Ecosystem Services and Management 8:17-25.

Mayaux, P., H. Eva, J. Gallego, A. H. Strahler, M. Herold, S. Agrawal, S. Naumov, E. E. De Miranda, C. M. Di Bella, C. Ordoyne, Y. Kopin, and P. S. Roy. 2006. Validation of the Global Land Cover 2000 Map. IEEE Transactions on Geoscience and Remote Sensing 44:1728-1739.

MEA (Millenium Ecosystem Assessment). 2005. Millennium ecosystem assessment: ecosystems and human well-being: synthesis. Island Press, Washington, DC.

Mehaffey, M., E. Smith, R. van Remortel. 2012. Midwest U.S. landscape change to 2020 driven by biofuel mandates. Ecological Applications 22:8-19.
Mehaffey, M., R. van Remortel, E. Smith, and R. Bruins. 2011. Developing a dataset to assess ecosystem services in the Midwest United States. International Journal of Geographical Information Science 25:681-695.

Mertes, L. A. K. 2002. Remote sensing of riverine landscape. Freshwater Biology 47:799-816.

Meyer, J. L., M. J. Sale, P. J. Mulholland, and N. Leroy Poff. 1999. Impacts of climate change on aquatic ecosystem functioning and health. Iournal of the American Water Resources Association 35:1373-1386.

Milcu, A. I., J. Hanspach, D. Abson, and J. Fischer. 2013. Cultural ecosystem services: a literature review and prospects of future research. Ecology and Society 18:565-598.

Mueller, R., and M. Ozga. 2002. Creating a cropland data layer for an entire state. Proceedings of the 2002 ACSM-ASPRS Conference, 19-26 April 2002, Washington DC.

Mulla, D. J. 2013. Twenty five years of remote sensing in precision agriculture: key advances and remaining knowledge gaps. Biosystems Engineering 114:358-371.

Muller, M. R., and J. Middleton. 1994. A Markov model of landuse change dynamics in the Niagara Region, Ontario, Canada. Landscape Ecology 9:151-157.

Nedkov, S., and B. Burkhard. 2012. Flood regulating ecosystem services: mapping supply and demand in the Etropole Municipality, Bulgaria. Ecological Indicators 21:67-79.

Nelson, E., G. Mendoza, J. Regetz, S. Polasky, H. Tallis, D. R. Cameron, K. M. A. Chan, G. C. Daily, J. Goldstein, P. M. Kareiva, E. Lonsdorf, R. Naidoo, T. H. Rickets, and M. R. Shaw. 2009. Modeling multiple ecosystem services, biodiversity conservation, commodity production, and trade-offs at landscape scales. Frontiers in Ecology and Environment 7:4-11.

Nohara, D., A. Kitoh, M. Hosaka, and T. Oki. 2006. Impact of climate change on river discharge projected by multimodel ensemble. Lournal of Hydrometeorology 7:1076-1089.

NRCS (National Resources Conservation Service). 1995. Soil Survey Geographic (SSURGO) data base: data use information. Miscellaneous Publication 1527. U.S. Department of Agriculture, Natural Resources Conservation Service, National Soil Survey Center, Lincoln, Nebraska.

Ozdogan, J. M. and G. Gutman. 2008. A new methodology to map irrigated areas using multi-temporal MODIS and ancillary data: an application example in the continental U.S. $\underline{\mathrm{Re}-}$ mote Sensing of Environment 112:3520-3537.

Palmer, M. A., C. A. Reidy Liermann, C. Nilsson, M. Flörke, J. Alcamo, P. S. Lake, and N. Bond. 2008. Climate change and the world's river basins: anticipating management options. Frontiers in Ecology and the Environment 6:81-89.

Petts, G. E. 1996. Water allocation to protect river ecosystems. Regulated Rivers: Research and Management 12:353-365.

Petts, G. E. 2009. Instream flow science for sustainable river management. Iournal of the American Water Resources Association 45:1071-1086.

Petts, G. E., and C. Amoros. 1996. Fluvial hydrosystems. Chapman and Hall, London, UK.

Pistorius, T., H. Schaich, G. Winkel, T. Plieninger, C. Bieling, W. Konold, and K.-R. Volz. 2012. Lessons for REDDplus: a comparative analysis of the German discourse on forest functions and the global ecosystem services debate. Forest Policy and Economics 18:4-12. 
Plummer, M. L. 2009. Assessing benefit transfer for the valuation of ecosystem services. Frontiers in Ecology and the Environment 7:38-45.

Quinlan, J. R. 1993. C4.5: programs for machine learning. Morgan Kauffmann Publishers, San Francisco, California.

Richards, D. R., and D. A. Friess. 2015. A rapid indicator of cultural ecosystem service usage at a fine spatial scale: content analysis of social media photographs. Ecological Indicators 53:187-195.

Richter, B. D., R. Mathews, D. L. Harrison, and R. Wigington. 2003. Ecologically sustainable water management: managing river flows for ecological integrity. Ecological Applications 13:206-224.

Rosegrant, M. W., X. Cai, and S. A. Cline. 2002. World water and food to 2025: dealing with scarcity. International Food Policy Research Institute, Washington, DC.

Rutgers, M., H. J. van Wijnen, A. J. Schouten, C. Mulder, A. M. P. Kuiten, L. Brussaard, and A. M. Breure. 2012. A method to assess ecosystem services developed from soil attributes with stakeholders and data of four arable farms. Science of the Total Environment 415:39-48.

Schneiders, A., T. van Daele, W. van Landuyt, and W. van Reeth. 2012. Biodiversity and ecosystem services: complementary approaches for ecosystem management? Ecological Indicators 21:123-133.

Schröter, D., W. Cramer, R. Leemans, I. C. Prentice, M. B. Araújo, N. W. Arnell, A. Bondeau, H. Bugmann, T. R. Carter, C. A. Gracia, A. C. de la Vega-Leinert, M. Erhard, F. Ewert, M. Glendining, J. I. House, S. Kankaanpää, R. J. T. Klein, S. Lavorel, M. Lindner, M. J. Metzger, J. Meyer, T. D. Mitchell, I. Reginster, M. Rounsevell, S. Sabaté, S. Sitch, B. Smith, J. Smith, P. Smith, M. T. Sykes, K. Thonicke, W. Thuiller, G. Tuck, S. Zaehle, and B. Zierl. 2005. Ecosystem service supply and vulnerability to global change in Europe. Science 310:1333-1337.

Schulp, C. J. E., and R. Alkemade. 2011. Consequences of uncertainty in global-scale land cover maps for mapping ecosystem functions: an analysis of pollination efficiency. Remote Sensing 3:2057-2075.

Scolozzi, R., E. Morri, and R. Santolini. 2012. Delphi-based change assessment in ecosystem services values to support strategic spatial planning in Italian landscapes. Ecological Indicators 21:134-144.

Skokanová, H. 2013. Can we combine structural functionality and landscape services assessments in order to estimate the impact of landscape structure on landscape services? Moravian Geographical Reports 21:2-14.

Stoll, S., M. Frenzel, B. Burkhard, M. Adamescu, A. Augustaitis, C. Baeßler, F. J. Bonet, M. L. Carranza, C. Cazacu, and G. L. Cosor. 2015. Assessment of ecosystem integrity and service gradients across Europe using the LTER Europe network. Ecological Modelling 295:75-87.

Stürk, J., A. Poortinga, and P. H. Verburg. 2014. Mapping ecosystem services: the supply and demand of flood regulating services in Europe. Ecological Indicators 38:198-211.

Swanson, F. J., S. V. Gregory, J. R. Sedell, and A. G. Campbell. 1982. Land-water interactions: the riparian zone. Pages 267291 in R. L. Edmonds (editor). Analysis of coniferous forest ecosystems in the western United States. Hutchinson Ross Publishing, Stroudsburg, Pennsylvania.
Tabacchi, E., D. L. Correl, R. Hauer, G. Pinay, A. M. PlantyTabacchi, and R. C. Wissmar. 1998. Development, maintenance and role of riparian vegetation in the river landscape. Freshwater Biology 40:497-516.

Tallis, H., and S. Polasky. 2009. Mapping and valuing ecosystem services as an approach for conservation and natural-resource management. Annals of the New York Academv of Sciences 1162:265-283.

TEEB (The Economics of Ecosystems and Biodiversity). 2010a. The economics of ecosystems and biodiversity: ecological and economic foundations. Earthscan, London, UK.

TEEB (The Economics of Ecosystems and Biodiversity). 2010b. The economics of ecosystems and biodiversity for local and regional policy makers. Progress Press, Valletta, Malta.

TEEB (The Economics of Ecosystems and Biodiversity). 2010c. The economics of ecosystems and biodiversity: mainstreaming the economics of nature: a synthesis of the approach, conclusions, and recommendations of TEEB. Progress Press, Valletta, Malta.

Tockner, K., and J. A. Stanford. 2002. Riverine flood plains: present state and future trends. Environmental Conservation 29:308-330.

Tolkamp, G. W., C. A. van den Berg, G. J. M. M. Nabuurs, and A. F. M. Olsthoorn. 2006. Kwantificering van beschikbare biomassa voor bio-energie uit Staatsbosbeheerterreinen, Alterrarapport 138.0 (in Dutch). Alterra, Wageningen, The Netherlands.

Townshend, J., C. Justice, W. Li, C. Gurney, and J. McManus. 1991. Global land cover classification by remote sensing: present capabilities and future possibilities. Remote Sensing of Environment 35:243-255.

Turner, W., S. Spector, N. Gardiner, M. Fladeland, E. Sterling, and M. Steininger. 2003. Remote sensing for biodiversity science and conservation. Trends in Ecology and Evolution 18:306-314.

USDA NASS (US Department of Agriculture, National Agriculture Statistics Service). 2007. Crop yields for corn, soybean, wheat, hay. [online] National Agriculture Statistics Service, Washington, D.C. (Available from: http://www.nass.usda.gov /Data_and_Statistics/County_Data_Files/)

Van der Biest, K., D. Vrebos, J. Staes, A. Boerema, M. B. Bodí, E. Fransen, and P. Meire. 2015. Evaluation of the accuracy of land-use based ecosystem service assessments for different thematic resolutions. Journal of Environmental Management 156: 41-51.

Van der Molen, D. T., H. P. A. Aarts, J. J. G. M. Backx, E. F. M. Geilen, and M. Platteeuw. 2000. RWES aquatisch. RIZA rapport 2000.0.38. Rijksinstituut voor Integraal Zoetwaterbeheer en Afvalwaterbehandeling, Lelystad, The Netherlands. (Available from: http://publicaties.minienm.nl/documenten/rwes-aquatisch)

Van der Molen, D. T., N. Geilen, J. J. G. M. Backx, B. J. M. Jansen, and H. P. Wolfert. 2003. Water ecotope classification for integrated water management in The Netherlands. European Water Management Online. E-WAter documents 2003/03:1-14.

Van Wijnen, H. J., M. Rutgers, A. J. Schouten, C. Mulder, D. de Zwart, and A. M. Breure. 2012. How to calculate the spatial distribution of ecosystem services - natural attenuation as example from The Netherlands. Science of the Total Environment 415:49-55.

Vermaat, J., E. Ansink, M. Catalinas Perez, A. Wagtendonk, and R. Brouwer. 2013. Valuing the ecosystem services provided by European river corridors - an analytical framework. REFORM 
deliverable: D2.3 Analytical framework ecosystem services. Restoring rivers for effective catchment Management. Vrije Universiteit, Amsterdam, The Netherlands. (Available from: http://www.reformrivers.eu/deliverables/d2-3)

Villa, F., K. Bagstad, B. Voigt, G. Johnson, R. Portela, Honzák and D. Batker. 2014. A methodology for adaptable and robust ecosystem services assessment. PLoS ONE 9: e91001.

Vörösmarty, C., P. Green, J. Salisbury, and R. B. Lammers. 2000. Global water resources: vulnerability from climate change and population growth. Science 289:284-288.

Wallace, K. J. 2007. Classification of ecosystem services: problems and solutions. Biological Conservation 139:235-246.

Wang, G., Q. Fang, L. Zhang, W. Chen, Z. Chen, and H. Hong. 2010. Valuing the effects of hydropower development on watershed ecosystem services: case studies in the Jiulong River Watershed, Fujian Province, China. Estuarine, Coastal and Shelf Science 86: 363-368.

Ward, J. V., K. Tockner, D. B. Arscott, and C. Claret. 2002. Riverine landscape diversity. Freshwater Biology 47:517-539.
Weissteiner, C. J., M. Ickerott, M. Probeck, G. Ramminger, N. Clerici, H. Dufourmont, and A. M. Ribeiro de Sousa. 2016. Europe's green arteries-a continental dataset of riparian zones. Remote Sensing 8:1-27.

Wiens, J. A. 2002. Riverine landscapes: taking landscape ecology into the water. Freshwater Biology 47:501-515.

Willems, D., J. Bergwerff, and N. Geilen. 2007. RWES Terrestrisch. RIZA rapport 2007.030. Rijksinstituut voor Integraal Zoetwaterbeheer en Afvalwaterbehandeling, Lelystad, The Netherlands. (Available from: http://publicaties.minienm.nl/documenten/rwes -terrestrisch-actualisatie-ecotopenindeling-van-de-periodiek)

Xie, Y., Z. Sha, and M. Yu. 2008. Remote sensing imagery in vegetation mapping: a review. Journal of Plant Ecology 1:9-23.

Zhang, Y. K., and K. E. Schilling. 2006. Increasing streamflow and baseflow in Mississippi River since the 1940s: effect of land use change. Journal of Hydrology 324:412-422.

Zonneveld, I. S. 1989. The land unit-a fundamental concept in landscape ecology, and its applications. Landscape Ecology 3: 67-86. 